RC. US Army Corps

$-/ 3$ of Engineers

Waterways Experiment

Station

\title{
Investigation of Wave Grouping Effects on the Stability of Stone-Armored, Rubble-Mound Breakwaters
}

by Robert D. Carver, Brenda J. Wright

\author{
Metr Reference Room \\ Universty of llinois \\ B106 Newmark CE Lab \\ 205 North Mathews Avenus \\ Urbarne, Minois 61801
}

Approved For Public Release; Distribution Is Unlimited

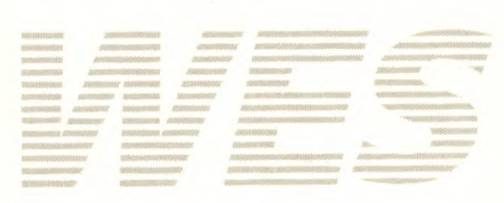

